most cases of diffuse systemic scleroderma, the onset of the illness is marked by involvement of the viscera and it is well known that scleroderma may be present for many years before the development of clinically detectable visceral disease or it may continue to exist indefinitely with little or no evidence of systemic dysfunction. Not infrequently, however, one encounters patients in whom the occurrence of visceral changes typical of systemic scleroderma antedates the appearance of dermal changes, thus creating as it were a state of progressive systemic sclerosis sine scleroderma as described by Rodnan \& Fennel (1962).

In most such cases this condition is only temporary, typical skin changes becoming apparent within a period of several months to a year. In the patient presented the skin changes became apparent 7 years after the visceral involvement. This is much longer than in any case found in the literature. Even the three patients described by Rodnan \& Fennel (1962) as systemic sclerosis sine scleroderma, died within 3 years of the onset of the visceral changes. The other points of interest are:

(i) That the patient was thought to be suffering and was treated for achalasia for 7 years.

(ii) That involvement of the intestine presented 6 years after the achalasia was diagnosed, as subacute intestinal obstruction and led to laparotomy.

(iii) The presence of Raynaud's phenomenon in this patient is in keeping with the previous observations that involvement of the oesophagus with aperistalsis is more frequent in patients with Raynaud's phenomenon (Stevens et al., 1964).

\section{References}

Rodnan, G.P. \& Fennell, R.H. JR (1962) Progressive systemic sclerosis sine scleroderma. Journal of the American Medical Association, 180, 665.

Stevens, M.B., Hookman, P., Siegel, C.I., Esterly, J.R., Shulman, L.E. \& Hendrix, T.R. (1964) Aperistalsis of the oesophagus in patients with connective tissue disorders and Raynaud's phenomenon. New England Journal of Medicine, 270, 1218.

\title{
Unusual presentation of multiple myeloma
}

\author{
ANDREW G. A. HeFFERnAN* \\ M.D., M.Sc. \\ Mater Misericordiae Hospital, Dublin, 7
}

THIS is the case report of a patient who presented with spontaneous hypoglycaemia and was found to have multiple myeloma. A recent review of multiple myeloma (Healy, 1968), makes no mention of spontaneous hypoglycaemia among the metabolic disturbances that can occur in patients with this condition.

\section{Case report}

M.H., a 61-year-old spinster who was certified blind, because of congenital chorioiditis and was a known hypertensive for some time, but had received no treatment was admitted to the Mater Misericordiae Hospital on 24 December, 1967. She became confused with left-sided weakness following her midday meal, on that day. Her family doctor who examined her at the time found her blood pressure

\footnotetext{
*Present position and address: Lecturer in Medicine, University College, and St Vincent's, Dublin, 4.
}

was $250 / 120 \mathrm{mmHg}$ and that she had a left hemiparesis with an extensor planter response.

On admission about $4 \mathrm{hr}$ later, she was lucid and able to carry on an intelligent conversation, but was confused as to events from mid-day onwards. Vital signs on admission of this obese patient were temperature $98^{\circ} \mathrm{F}$, pulse 80 and repiration $20 / \mathrm{min}$. Her blood pressure was $240 / 150 \mathrm{mmHg}$. She had cardiomegaly but no evidence of congestive cardiac failure. Also she had a left strabismus and bilateral extensive chorioidal and retinal atrophy. Her neurological system was intact with bilateral flexor plantar responses.

The impression was that she had a transient cerebrovascular episode related to her hypertension and she was treated initially with reserpine intramuscularly and later methyldopa and debrisoquine $(1.5 \mathrm{~g}$ and $20 \mathrm{mg}$ daily). Her blood pressure responded well to this therapy. 
Investigations. Urinalysis, blood urea, electrolytes, uric acid, cholesterol, calcium, alkaline phosphatase and liver function tests were normal. Cerebrospinal fluid including WR was negative and an EEG showed no definite abnormality. Haemoglobulin was $10.98 \mathrm{~g} / 100 \mathrm{ml}, \mathrm{MCHC} 31 \%$, WCC $6800 / \mathrm{mm}^{3}$ : neutrophils $51 \%$, eosinophils $12 \%$, lymphocytes $34 \%$, monocytes $3 \%$ and platelets present in adequate numbers. The ECG showed left ventricular hypertrophy and there was moderate cardiac enlargement, mainly of the left ventricle on chest X-ray. $\mathrm{X}$-rays of the skull revealed widespread osteolytic lesions and similar lesions were present in X-rays of the pelvis. These findings, together with an ESR of $105 \mathrm{~mm}$ in $1 \mathrm{hr}$, suggested that diagnosis of multiple myeloma. Bone marrow from the sternum and cervical spine showed a marked increase in normal and abnormal plasma cells, partially replacing the normal elements. The picture was diagnostic of myeloma. No other neoplastic type cells were seen.

Total proteins were $7.6 \mathrm{~g} / 100 \mathrm{ml}$ (albumin 3.4 $\mathrm{g} / 100 \mathrm{ml}$, globulin $4 \cdot 2 \mathrm{~g} / 100 \mathrm{ml}$ ). Electrophoresis of the patient's serum on paper and cellulose acetate revealed an abnormal protein with the mobility of a fast $\gamma$-globulin. The distribution of the serum proteins was as follows: Albumin $44.8 \% ; \alpha_{1}-$ globulin $2.6 \% ; \quad \alpha_{2}$-globulin $10.5 \% ; \quad \beta$-globulin $13.2 \%$; M-fraction $26.3 \%$; $\gamma$-globulin $2.6 \%$. Immunoelectrophoresis showed a reduction of IgG and $\operatorname{IgM}$, but a precipitin line characteristic of monoclonal gammopathy was seen with anti-IgA. Immunochemical quantitation using Hyland immunodiffusion plates confirmed the immunoelectrophoretic findings: IgG $370 \mathrm{mg} / 100 \mathrm{ml}$ (normal 1206 \pm 319 ), IgA $2300 \mathrm{mg} / 100 \mathrm{ml}$ (normal $288 \pm 121$ ), IgM $14 \mathrm{mg} / 100 \mathrm{ml}$ (Normal $80 \pm 29$ ). Urine concentrated sixty-fold by dialysis against $25 \%$ polyvinyl-pyrrolidone and examined by paper electrophoresis was negative for Bence-Jones protein. Test for cryoglobulins and direct Coombs' test were negative.

Progress. The patient's condition was satisfactory until the seventeenth hospital day when she became suddenly unconscious and developed a left-sided flaccid paralysis and extensor plantar response. Within $3 \mathrm{hr}$ the patient had completely recovered, but she could not remember anything of the attack. This attack was similar to that responsible for her admission. Two days later, about $1 \mathrm{hr}$ after her lunch, a similar episode occurred with complete recovery within a few hours. A specimen of blood taken for blood sugar estimation during this attack was found to be $18 \mathrm{mg} / 100 \mathrm{ml}$. A further similar attack on the twenty-first hospital day responded immediately to intravenous dextrose. Subsequent episodes on the thirty-second and thirty-third hospital day, which responded dramatically to oral glucose were associated with blood sugars of 19 and $10 \mathrm{mg} / 100 \mathrm{ml}$ respectively.

Tests of pituitary, thyroid, adrenal cortex and medulla, urinary excretion of 5 HIAA, and plasma, and urinary amino acids were all within normal limits. Thin-layer chromatography revealed no abnormal levels of tryptophan or its metabolites in blood or urine. Glucose, tolbutamide and glucagon tolerance tests (Table 1-3) were not diagnostic of any specific cause of hypoglycaemia. Prolonged fasting (14 hr) produced hypoglycaemia with a blood sugar of $17 \mathrm{mg} / 100 \mathrm{ml}$ and serum insulin of $106 \mu \mathrm{U} / \mathrm{ml}$ and leucine (Table 4) also induced hypoglycaemia. Laparotomy to rule out insulinoma was considered but the patient refused operation. In fact, she was averse to any form of treatment and so specific chemotherapy was not initiated.

She was started on a 2500 calorie diet which consisted of carbohydrate $230 \mathrm{~g}$, protein $120 \mathrm{~g}$ and fat $100 \mathrm{~g}$. This was taken as six meals per day. She was discharged on 26 February 1968 on this diet and advised to take supplemental glucose if necessary. Her antihypertensive therapy was also continued.

\section{Second admission (16 April, 1968)}

The patient was re-admitted because of severe lumbar pain and X-rays of this area showed marked destructive changes in L3 and 4. She had remained free of hypoglycaemic attacks since discharge,

TABLE 1. Glucose tolerance test ( $50 \mathrm{~g}$ oral)

\begin{tabular}{ccc}
\hline $\begin{array}{c}\text { Time } \\
(\mathrm{min})\end{array}$ & $\begin{array}{c}\text { Blood sugar } \\
(\mathrm{mg} / 100 \mathrm{ml})\end{array}$ & $\begin{array}{c}\text { Serum insulin } \\
(\mu \mathrm{U} / \mathrm{ml})\end{array}$ \\
\hline Zero & 48 & $23 \cdot 6$ \\
30 & 126 & $17 \cdot 9$ \\
60 & 151 & $17 \cdot 9$ \\
90 & 143 & $29 \cdot 3$ \\
120 & 140 & $25 \cdot 8$ \\
150 & 71 & $25 \cdot 8$ \\
180 & 48 & $27 \cdot 2$ \\
210 & 33 & $23 \cdot 6$ \\
240 & 35 & $27 \cdot 2$ \\
270 & 37 & $35 \cdot 8$ \\
300 & 46 & $43 \cdot 2$ \\
\hline
\end{tabular}

TABLE 2. Tolbutamide tolerance test ( $1.0 \mathrm{~g} \mathrm{I.V.)}$

\begin{tabular}{ccc}
\hline $\begin{array}{c}\text { Time } \\
(\mathrm{min})\end{array}$ & $\begin{array}{c}\text { Blood sugar } \\
(\mathrm{mg} / 100 \mathrm{ml})\end{array}$ & $\begin{array}{c}\text { Serum insulin } \\
(\mu \mathrm{U} / \mathrm{ml})\end{array}$ \\
\hline Zero & 40 & $4 \cdot 2$ \\
5 & 39 & $2 \cdot 8$ \\
10 & 43 & $14 \cdot 1$ \\
15 & 32 & $15 \cdot 5$ \\
20 & 28 & - \\
$30^{*}$ & 29 & $8 \cdot 5$ \\
\hline
\end{tabular}

* This was stopped at this stage because of symptoms of hypoglycaemia. 
TABLE 3. Glucagon tolerance test (1.0 mg I.M.)

\begin{tabular}{ccc}
\hline $\begin{array}{c}\text { Time } \\
(\mathrm{min})\end{array}$ & $\begin{array}{c}\text { Blood sugar } \\
(\mathrm{mg} / 100 \mathrm{ml})\end{array}$ & $\begin{array}{c}\text { Serum insulin } \\
(\mu \mathrm{U} / \mathrm{ml})\end{array}$ \\
\hline Zero & 33 & $23 \cdot 6$ \\
20 & 86 & $22 \cdot 2$ \\
30 & 82 & $51 \cdot 3$ \\
45 & 66 & $20 \cdot 0$ \\
60 & 52 & $20 \cdot 0$ \\
80 & 44 & - \\
90 & 33 & $27 \cdot 2$ \\
120 & 32 & $30 \cdot 1$ \\
\hline
\end{tabular}

TABLE 4. Leucine tolerance test $(150 \mathrm{mg} / \mathrm{kg}$ oral)

\begin{tabular}{ccc}
\hline $\begin{array}{c}\text { Time } \\
(\mathrm{min})\end{array}$ & $\begin{array}{c}\text { Blood sugar } \\
(\mathrm{mg} / 100 \mathrm{ml})\end{array}$ & $\begin{array}{c}\text { Serum insulir } \\
(\mu \mathrm{U} / \mathrm{ml})\end{array}$ \\
\hline Zero & 61 & $32 \cdot 2$ \\
10 & 55 & $100 \cdot 3$ \\
20 & 40 & $45 \cdot 8$ \\
30 & 35 & $50 \cdot 1$ \\
45 & 26 & $45 \cdot 8$ \\
60 & 24 & $34 \cdot 4$ \\
\hline
\end{tabular}

though her fasting blood sugar was $30 \mathrm{mg} / 100 \mathrm{ml}$. Her blood pressure was well controlled at about $160 / 100 \mathrm{mmHg}$ with methyldopa $1.5 \mathrm{~g}$ and debrisoquine $20 \mathrm{mg}$ daily. No neurological deficit was found and the EEG was unchanged from the previous record. Haemoglobulin was $9 \cdot 1 \mathrm{~g} / 100 \mathrm{ml}$, MCHC $30 \%$ WCC $7200 / \mathrm{mm}^{3}$ and ESR $106 \mathrm{~mm}$ in $1 \mathrm{hr}$. Urinalysis was negative. Blood urea, serum electrolytes and calcium were within normal limits. The patient was transferred to St Anne's Hospital for deep X-ray therapy. Following this, there was marked improvement in her lumbar pain and she was discharged.

Though the patient was free from hypoglycaemic attacks, the blood sugar was still low so it was decided to add diazoxide $5 \mathrm{mg} / \mathrm{kg}$ daily in two divided doses while continuing her dietary regimen. This was only maintained for 5 weeks. Following this her progress was fairly satisfactory until October 1968, when she rapidly deteriorated with increasing pain in her left shoulder, recurrent chest infection and congestive cardiac failure. Her subsequent course was downhill and she died at home in May 1969. No necropsy was performed.

\section{Discussion}

A number of metabolic disturbances such as hypercalcaemia, hyperuricaemia, hyperlipidaemia and generalized amino-aciduria, with an acquired Fanconi syndrome have been reported in association with multiple myeloma. There is no report of spontaneous hypoglycaemia occurring in patients with myelomatosis. This case of multiple myeloma associated with spontaneous hypoglycaemia meets with the criteria of the trial of Whipple $(1938,1944)$. The important question whether there was another cause for the hypoglycaemia or whether it was caused by the myelomatosis per se cannot definitely be decided. Spontaneous hypoglycaemia has been recorded with a variety of extrapancreatic neoplasms and recently it has been reported in three cases of chronic myelogenous leukaemia (Tarail, 1960; Tashima, Cala \& Thomas, 1968; Gamble, 1969). Prolonged fasting producing hypoglycaemia with a high serum insulin level and the leucine-induced hypoglycaemia are in favour of the diagnosis of pancreatic islet cell adenoma. This was not supported by the tolbutamide test. Necropsy would have been desirable to completely rule out this cause. Furthermore, increased plasma immunoreactive insulin has been reported in a case of hypoglycaemia-producing bronchial carcinoid tumour (Shames, Dhurandhar \& Blackard, 1968), the inference from this being that the neoplastic cells in the patient described herein could be producing the raised serum insulin in response to fasting and leucine stimulation.

An interesting facet of this patient was her reluctance to be treated. She refused operation and specific chemotherapy. However, she did take her antihypertensive drugs and because of her severe backache she agreed to deep X-ray therapy. She tried diazoxide for about 5 weeks. This increased her fasting blood sugar without any change in serum insulin levels. Diazoxide had no effect on the elevated IgA levels, though depression of IgG levels have been reported with this therapy (Baker \& Miller, 1967).

\section{Acknowledgment}

I wish to thank Professor T. B. Counihan for allowing me to study his patient and for his constant help and advice. I am grateful to Dr J. G. Devlin for the immunoassay of serum insulin. Allen \& Hanburys Ltd kindly supplied the diazoxide.

\section{References}

BAKeR, L. \& Miller, M.E. (1967) Preliminary report: depression of immunoglobulin-G (IgG) levels associated with diazoxide therapy. Metabolism, 16, 964.

GamBle, W.S. (1964) Hypoglycemia secondary to chronic myelogenous leukemia. Southern Medical Journal, 62, 680.

Healy, J.B. (1968) The disease, myelomatosis. Irish Journal of Medical Science, 1, 211.

Shames, J.M., Dhurandhar, N.R. \& Blackard, W.G. (1968) Insulin-secreting bronchial carcinoid tumor with widespread metastases. American Journal of Medicine, 44, 632.

TARAIL, R. (1960) Hypoglycemia in a patient with chronic myelocytic leukemia. New York Journal of Medicine, 60, 3433.

Tashima, C.K., Cala, R.G. \& Thomas, W. (1968) Symptomatic hypoglycemia in terminal leukemia. Journal of the American Medical Association, 204, 107.

WhIPPLE, A.O. (1938) The surgical therapy of hyperinsulinism. Journal international de chirurgie, 3, 237.

WhIPPLE, A.O. (1944) Hyperinsulism in relation to pancreatic tumours. Surgery, 16, 289. 